DOI https://doi.org/10.15589/znp2019.3(477).5

УДК 537.868

\title{
THE INFLUENCE OF ELECTROMAGNETIC FIELDS DIFFERENT FREQUENCY BANDS ON DIFFUSION PROCESSES IN ELECTROCONDUCTIVE MATERIALS
}

\section{ВПЛИВ ЕЛЕКТРОМАГНІТНИХ ПОЛІВ РІЗНИХ ЧАСТОТНИХ ДІАПАЗОНІВ НА ДИФУЗІЮ В ЕЛЕКТРОПРОВІДНИХ МАТЕРІАЛАХ}

\author{
Ihor A. Kolesnyk \\ kolesnikigor123@gmail.com \\ ORCID: 0000-0002-1554-9632
}

\author{
І. А. Колесник, \\ аспірант
}

\author{
Admiral Makarov National University of Shipbuilding, Mykolaiv \\ Національний університет кораблебудування імені адмірала Макарова, м. Миколаӥв
}

\begin{abstract}
The article discusses the features of diffusion processes during heating of electrically conductive materials. The aim of the work is comparing and assessing the effect of ultraviolet, microwave and infrared radiation on diffusion processes when heating electrically conductive materials. The basis for mathematical and experimental studies was a comparison of the quantum energy in the case of different frequency ranges of radiation. It has been demonstrated that the quantum energy in UV radiation is sufficient to activate stimulated emission. This leads to the release of additional heat and, consequently, to the acceleration of the heating process. The mathematical part of the work consists in constructing the heat balance equation, which takes into account the following components: heat generated by radiators; heat absorbed by the powder billet; heat arising from Thomson scattering and heat loss. The duration of heating any electrically conductive material to a given temperature can be founded from the heat balance equation. The experimental part of the work required the creation of a facility equipped with ultraviolet emitters for comparative analysis with an existing muffle furnace. In order to conduct reliable experiments, the created installation had the same volume of the working chamber with the existing muffle furnace and the same power. The calculated data on the duration of heating to temperature $873 \mathrm{~K}$ differed significantly: vacuum muffle furnace (IR radiation) - $920 \mathrm{c}$; vacuum unit equipped with UV emitters - $371 \mathrm{c}$. The work substantiates the efficiency and economic feasibility of using UV radiation in the heating processes of metal powders. Results: the advantage of ultraviolet (UV) radiation over infrared (IR) and microwave (MX) radiation during the heating of metal billets is proved. Scientific novelty: using of electromagnetic radiation UV range in the heating processes of electrically conductive materials can significantly reduce the heating time of the metal powder material and the technological cycle. Practical significance: the materials of this work can be used to increase efficiency and accelerate such a technological process as sintering of metal powders.
\end{abstract}

Key words: quantum energy; radiation; diffusion; energy level; Thomson scattering; thermal balance; cross section of the transition.

Анотація. У статті йдеться про особливості дифузійних процесів при нагріванні електропровідних матеріалів. Метою роботи є зіставлення й оцінка впливу ультрафіолетового (УФ), мікрохвильового (МВ) та інфрачервоного (ІЧ) випромінювання на дифузійні процеси при нагріванні електропровідних матеріалів. Підставою для проведення математичного й експериментального досліджень було порівняння величини енергії кванта у разі різних частотних діапазонів випромінювання. Продемонстровано, що енергія кванта при УФ випромінюванні є достатньою для активації вимушеного випромінювання. Це призводить до виділення додаткового тепла і до прискорення процесу нагрівання. Математична частина роботи полягає у побудові рівняння теплового балансу, яке враховує такі складники: тепло, виділене випромінювачами; тепло, поглинене порошковою заготовкою; тепло, яке виникає за рахунок томсонівсьького розсіювання та втрати тепла. За допомогою цього рівняння можна знайти тривалість нагрівання будь-якого електропровідного матеріалу до заданої температури. Експериментальна частина роботи потребувала створення установки, обладнаної ультрафіолетовими випромінювачами, для порівняльного аналізу з існуючою муфельною піччю. 3 метою проведення достовірних експериментів створена установка мала однаковий об'єм робочої камери з існуючою муфельною піччю й однакову потужність. Розрахункові дані тривалості нагріву до температури 873 К істотно відрізнялися: вакуумна муфельна піч (ІК випромінювання) - 920 с; вакуумна установка, обладнана УФ випромінювачами - 371 с. У роботі обгрунтовується ефективність і економічна доцільність використання УФ випромінювання в процесах нагрівання металевих порошків. Результати: доведено перевагу ультрафіолетового (УФ) випромінювання над інфрачервоним (ІЧ) і мікрохвильовим (MX) випромінюванням у процесі нагрівання металевих заготовок. Наукова новизна: використання електромагнітного випромінювання УФ діапазону в процесах нагрівання електропровідних матеріалів дозволяє значно скоротити тривалість нагрівання заготовки та технологічного циклу загалом. Практична значимість: матеріали цієї роботи можуть бути використані з метою підвищення ефективності та прискорення такого технологічного процесу, як спікання металевих порошків.

Ключові слова: енергія кванта; випромінювання; дифузія; енергетичний рівень; томсонівсььке розсіювання; тепловий баланс; перетин переходу. 


\section{ПОСТАНОВКА ЗАДАЧІ}

В усі часи одними з основних напрямів діяльності дослідників є пошук більш ефективних, продуктивних та економічних технологій виробництва. У нашій роботі йдеться про вдосконалення процесу нагріву електропровідних матеріалів. Останні десятиліття характеризуються активним дослідженням процесів спікання металічних порошків. Така тенденція пов'язана з дедалі частішою заміною традиційної технології лиття металу на технологію спікання. Метод спікання складається 3 двох основних стадій: надання металічному порошку заданої форми необхідної деталі та подальшого спікання. Іноді ці стадії проводять одночасно. Звичайно процес нагріву проводять у муфельних печах, тобто переважно інфрачервоним випромінюванням. Основною задачею нашої роботи $€$ порівняльний аналіз процесу нагріву пресованих заготовок із карбонільного заліза при інфрачервоному, мікрохвильовому й ультрафіолетовому випромінюванні.

\section{АНАЛІЗ ОСТАННІХ ДОСЛІДЖЕНЬ І ПУБЛІКАЦІЙ}

Спіканням металевих порошків і супутніх дифузійних процесів займається порошкова металургія. Це науково-технічна галузь об'єднує різні методи отримання порошкових матеріалів і виробляє методи перетворення металевих порошків у кінцевий виріб без застосування технології лиття. Традиційно процес спікання проводять при температурах нижче точки плавлення матеріалу. Винятком є технологія спікання з присутністю рідкої фази. Як приклад можна навести спікання суміші залізного й алюмінієвого порошків при температурі 1200 К. Щодо технологій спікання, їх існує велика кількість. Серед найбільш відомих можна перерахувати такі, як іскро-плазмове спікання [1], гаряче пресування [2], спікання в муфельних печах. Найбільш практичними і продуктивними методами є гаряче пресування і спікання в муфельній печі. Суть технології гарячого пресування полягає при одночасному впливі механічного тиску i теплового впливу на підготовлену засипку порошку. Найбільшою популярністю має метод спікання в муфельній печі, який проводять за 2 стадії: попереднє пресування засипки і подальше спікання. Ця технологія відрізняється високою продуктивністю і практичністю. Однак вона також має 2 серйозні недоліки: низький ККД печей і тривалий час розігріву заготовки до необхідної температури (від 1300 К і вище). Проведений пошук сучасних наукових робіт, пов'язаних із питаннями впливу електромагнітних полів різних частотних діапазонів на дифузійні процеси в електропровідних матеріалах, на жаль, не дав необхідного результату. Однак є кілька відомих дослідників, які зробили величезний внесок у розвиток порошкової металургії. Серед них Г.А. Лібенсон [3;
4], С.С. Кипарисов [5], Г.В. Комарницький, С.А. Цукерман [6], Б.Ф. Айзенколь [7], М.Н. Лібенсон [8; 9]. Саме їх роботи стали основою для сучасного вивчення процесів, що протікають при спіканні порошкових матеріалів. Проведені теоретичні й експериментальні дослідження $є$ базою для сьогоднішніх дослідників різних ефектів і дифузійних процесів при спіканні порошків. Щодо сучасних дослідників, то можна відзначити роботи В.Ф. Мазанко [10], О.В. Покоєва [11; 12], В.О. Мілютин [13; 14]. Детально вивчивши процеси й ефекти, які лежать в основі технології спікання в муфельних печах та спіканні загалом, нами був запропонований спосіб значно скоротити тривалість досягнення температури ізотермічної витримки за рахунок підвищення частоти електромагнітного випромінювання.

\section{ВІДОКРЕМЛЕННЯ НЕВИРІШЕНИХ РАНІШЕ ЧАСТИН ЗАГАЛЬНОЇ ПРОБЛЕМИ}

Підставою для проведення нашого дослідження є відсутність вивчення впливу ультрафіолетового випромінювання на процеси дифузії при нагріві електропровідних матеріалів. Результати роботи можуть дати відповідь на питання про ефективність і доцільність використання УФ-випромінювання у процесах спікання.

Метою дослідження $є$ математичне й експериментальне доведення переваги використання ультрафіолетового випромінювання у процесах нагріву електропровідних матеріалів.

Методи, об'скт та предмет дослідження

Матеріал роботи є результатом експериментального та математичного порівняння тривалості процеси нагріву порошкової заготовки до температури ізотермічної витримки. Математичний порівняльній аналіз грунтується на проведених розрахунках згідно 3 побудованим рівнянням теплового балансу. Експериментальною частиною роботи є проектування та реалізація печі ультрафіолетового випромінювання аналогічної традиційній муфельній печі з метою отримання достовірних даних. Об'єктом дослідження є вплив випромінювання різного частотного діапазону на процес нагріву електропровідних матеріалів. Предметом є залежність тривалості нагріву металічної заготовки до необхідної температури від природи випромінювання.

\section{ОСНОВНИЙ МАТЕРІАЛ}

Дифузія атомів при спіканні безпосередньо пов'язана 3 атомними механізмами, за якими здійснюються дифузійні стрибки. Відомо, що величина енергії активації дифузії $Q$ (1) є сумою енергії виникнення вузлової вакансії $E_{f}$ й енергії міграції атома по вузлах гратки структур речовини $E_{m}[15 ; 16]$

$$
\mathrm{Q}=\mathrm{E}_{\mathrm{f}}+\mathrm{E}_{\mathrm{m}}
$$

У рамках вакансійного механізму дифузії передбачається, що для переходу атома з вузла у вакансію 


\section{ЕЛЕКТРОЕНЕРГЕТИКА, ЕЛЕКТРОТЕХНІКА ТА ЕЛЕКТРОМЕХАНІКА № 3 - 2019}

йому потрібно подолати потенційний бар'єр величиною $Q$. На величину коефіцієнта дифузії впливають два основні параметри: енергія активації дифузії та досягнута температура досліджуваного матеріалу внаслідок нагрівання падаючим електромагнітним випромінюванням.

Будь-який процес спікання умовно ділиться на дві основні стадії:

- $\quad$ нагрів заготовки до заданої температури спікання,

- $\quad$ ізотермічний нагрів (витримка заготовки при певній величині температури).

Великий час розігріву заготовки на першому етапі спікання негативно впливає на властивості одержуваних матеріалів, такі як пористість, пружність, щільність та інші важливі параметри [17]. Тому більш ефективні способи спікання - ті, які дозволяють значно швидше розігріти заготовку (за кілька хвилин) до ізотермічної температури спікання.

Як відомо з квантової фізики, атом може поглинати енергію тільки окремими квантами. Енергія кванта (2) визначається за формулою Планка:

$$
E_{\kappa в}=h v[Д ж],
$$

де $h[$ Дж·с $]$ - постійна Планка,

$v\left[\frac{1}{c}\right]-$ частота випромінювання електромагнітного поля.

Розрахуємо енергію кванта для різних значень частот електромагнітних коливань 3 метою порівняння їх величини.

У разі мікрохвильового випромінювання (МХ) $\left(v=10^{9}\right.$ Гц ) величина кванта становить

$$
E_{\text {мік }}=h v=6.626 \cdot 10^{-25} \text { Дж }=4.125 \cdot 10^{-6} \mathrm{eB} ;
$$

для інфрачервоного випромінювання $\left(v=10^{12} \Gamma ц\right):$

$$
E_{i ч}=h v=6.626 \cdot 10^{-22} \text { Дж }=4.125 \cdot 10^{-3} e B ;
$$

для ультрафіолетового випромінювання $\left(v=10^{15} \Gamma ц\right)$ :

$$
E_{y \phi}=h v=6.626 \cdot 10^{-19} \text { Дж }=4.125 \mathrm{eB} .
$$

Значення енергії активації $Q$ можна знайти в довідкових даних для кожної речовини [18]. Ця величина, наприклад, для заліза становить від 1,5 до 2,5 еВ залежно від типу дифузії. Як бачимо, енергія поглиненого фотона ультрафіолетового діапазону $(4,125$ eВ) цілком достатня для переміщення атома в вакансію.

Виходячи 3 класичних уявлень (тобто з хвильової теорії), процес поглинання енергії атомом має такий фізичний механізм [19]. Зустрічаючи на шляху свого поширення якусь речовину, EMB (електро-магнітне випромінювання) залучає в коливальний процес його атомні частки, що володіють зарядом (електрони, іони та ін.), на що йде частина енергії хвилі. Коливання мікрочастинок, у свою чергу, також породжують вторинні електромагнітні коливання, когерентні падаючій хвилі. Енергія падаючого випромінювання переходить також у енергію збудження коливань кристалічної решітки, тобто на нагрів речовини. Збільшення частоти ЕМВ призводить до різкого зростання енергії кванта, наближаючись до значення бар'єру енергетичного переходу атома у збуджений стан (для атома заліза близько $8 \mathrm{eB}$ ). Електромагнітне випромінювання, пронизуючи яку-небудь речовину, віддає свою енергію його атомним часткам - i насамперед електронам. Це призводить до внутрішніх енергетичних переходів мікрочастинок з одного стану в інший і зводиться до двох пов'язаних між собою процесів. По-перше, до поглинання енергії електромагнітного поля незбудженими атомними частками; по-друге, до перетворення внутрішньої енергії збуджених атомних частинок в енергію коливань в оптичному діапазоні частот, тобто до появи випромінювання, яке може набувати форми спонтанного (самовільного) й індукованого випромінювань. Залежно від конкретного розподілу часток по енергіях може переважати той чи інший варіант. Якщо спікаєма речовина знаходиться у високочастотному полі ( $v \geq 10^{14} \Gamma ц$ ), то атоми можуть здійснити перехід на новий більш високий енергетичний рівень [20] внаслідок поглинання квантів енергії (фотонів). Як наслідок, атоми під впливом цього поля отримують можливість повертатися на основний нижній рівень і випромінювати також свій квант енергії. Таке випромінювання називається вимушеним або індукованим [21].

Другий параметр, що впливає на швидкість дифузії, - це температура речовини, яка насамперед визначається інтенсивністю падаючого випромінювання $I$ $I\left[\frac{\text { Дж }}{\mathrm{M}^{2} \mathrm{c}}\right]$. Знаючи інтенсивність випромінювання і площу поверхні заготовки $S\left[\mathrm{~m}^{2}\right]$, на яку падає випромінювання, можна знайти величину теплової енергії $Q$, що надходить у спікаєму заготовку за час $t$ [c].

$$
Q_{1}=I \cdot S \cdot t \cdot \alpha[\text { Дж], }
$$

де $\alpha$ визначає коефіцієнт поглинання випромінювання речовиною.

Водночас величина поглиненого тепла $Q$ визначається за різницею температури ізотермічної витримки $T_{1}$ і початкової температури $T_{0}, \Delta \mathrm{T}=\mathrm{T}_{1}-\mathrm{T}_{0}$ i теплоємністю металу $c_{\rho}[22]$.

$$
\mathrm{Q}_{2}=\mathrm{c}_{\rho} \cdot \mathrm{m} \cdot \Delta \mathrm{T}[\text { Дж }]
$$

де $m$ - маса заготовки.

При поглинанні атомом речовини енергії фотонів випромінювання відбувається виділення додаткового 
тепла всередині речовини вимушеним випромінюванням (квантовий ефект) у вигляді теплового нагріву кристалічної решітки. Позначимо цю величину $Q_{3}$. Ряд досліджень по взаємодії ЕМВ з речовиною називають цю додаткову енергію квантованою температурною добавкою [23].

Розглянемо заготовку, яку помістили в камеру електромагнітного нагрівання, що має площу поверхні $S$, бомбардовану потоком фотонів. Потік фотонів n через цю поверхню із загального числа фотонів, які утворюються всередині камери спікання, буде дорівнювати:

$$
\mathrm{n}=\frac{\mathrm{I} \cdot \mathrm{S}_{1}}{\mathrm{E}_{\mathrm{KB}} \cdot \mathrm{S}_{2}}\left[\frac{1}{\mathrm{M}^{2} \cdot \mathrm{c}}\right]
$$

тут $I$ - інтенсивність випромінювання всередині камери спікання, $S_{1}$ - площа поверхні заготовки, на яку падає світловий потік випромінювача, $S_{2}$ - загальна площа дзеркальної внутрішньої поверхні камери спікання (вакуумної камери), $E_{к в}$ - енергія фотона.

Значення виділеної енергії всередині заготовки за час $(t)$ за рахунок вимушеного випромінювання визначиться за формулою:

$$
\mathrm{Q}_{3}=\mathrm{N} \cdot \mathrm{W} \cdot \mathrm{E}_{\mathrm{кв}}[\text { Дж] }
$$

тут $N$ - кількість атомів, які здійснюють енергетичний перехід із вимушеним випромінюванням. При рівноваженій інверсній заселеності верхнього енергетичного і нижнього рівнів величину $N$ можна прийняти рівною половині кількості атомів у нагріваємій заготовці. $W$ - щільність ймовірності вимушеного випромінювання [24] дорівнює:

$$
\mathrm{W}=\mathrm{n} \cdot \delta
$$

де $\delta$ - перетин переходу. Цю величину можна розглядати як ефективний перетин атома [25], який орієнтований нормально до фотонного потоку і бере участь у взаємодії з індукованим випромінюванням.

Перетин переходу $\delta$ визначається по довжині випромінювання. Якщо довжина EMB менше ( $\lambda \approx 10^{-10} \mathrm{M}$ ), то випромінювання називається томсонівським розсіюванням [26]. У цьому разі атом сприймається фотоном «як єдине ціле».

Можна вважати, що джерелом розсіяного випромінювання $\epsilon$ пов'язані електрони атома, які починають резонувати під дією випромінювання і, внаслідок цього, випромінюють фотони такої самої частоти. Перетин томсонівського розсіювання залежить від кута розсіювання фотона $\theta$ :

$$
\delta(\theta)=0.5 r_{e}^{2}\left(1+\cos ^{2} \theta\right),
$$

де $\mathrm{r}_{\mathrm{e}}^{2}=\frac{\mathrm{e}^{2}}{\mathrm{~m}_{\mathrm{e}} \cdot \mathrm{c}^{2}}=2.8 \cdot 10^{-15} \mathrm{M}-$ класичний радіус електрона. Інтегруючи по всім $\theta$, можна отримати перетин повного томсонівського розсіювання. Ефективний перетин томсонівського розсіювання, розрахований на 1 електрон, становить:

$$
\delta=\left(\frac{8}{3}\right) \pi \cdot r_{e}^{2}=6.55 \cdot 10^{-30}{ }_{\mathcal{M}^{2}}=0.66 \text { барн. }
$$

Заготовка при нагріванні також є джерелом випромінювання. Виділене тепло розраховується за формулою:

$$
\mathrm{Q}_{4}=\mathrm{kT}^{4} \cdot \mathrm{S}_{1} \cdot \mathrm{t}[\text { Дж }],
$$

де $k\left[\frac{\text { Дж }}{\mathrm{M}^{2} \cdot \mathrm{K}^{4}}\right]$ - коефіцієнт Стефана-Больцмана. Величина $\theta €$ втратою енергії при нагріванні заготовки.

Складемо загальне рівняння теплового балансу (7) при нагріванні заготовки за рахунок дії електромагнітного поля:

$$
\mathrm{Q}_{1}+\mathrm{Q}_{3}-\mathrm{Q}_{4}=\mathrm{Q}_{2}
$$

У лівій частині виразу знаходиться тепло, що йде на нагрів заготовки, враховуючи теплові втрати, а у правій - ефективне (корисне) тепло. Корисне тепло спочатку витрачається на нагрів до потрібної температури, а потім - на процес ізотермічного спікання.

Підставляючи в (7) рівняння (3-6) отримаємо рівняння, що зв'язує температуру розігріву речовини заготовки з часом нагріву $t$ :

$$
I \cdot S \cdot t \cdot \alpha+N \cdot W \cdot E_{\kappa B}-k T^{4} \cdot S_{I} \cdot t=c_{\rho} \cdot m \cdot \Delta T
$$

Звідси, задаючи температуру заготовки, можна знаходити необхідний час нагрівання:

$$
t=\frac{c_{\rho} \cdot m \cdot \Delta T}{I \cdot S \cdot \alpha+N \cdot W \cdot E_{\kappa b^{-}} k T^{A} \cdot S_{l}}
$$

Проведемо порівняльні розрахунки тимчасових характеристик процесу спікання в муфельній печі, де йде нагрів речовини інфрачервоними випромінюваннями й у вакуумній камері з ЕМВ високої частоти (ультрафіолетового діапазону).

Для проведення розрахунків часу нагріву до певної температури задамо загальні початкові умови:

Спікається заготовка, спресована з карбонільного заліза дисперсністю 30 мкм, розташовувалася на дні циліндричної вакуумної камери із дзеркальними внутрішніми відбивачами, що фокусують випромінювання двох ламп ультрафіолетового діапазону на поверхню заготовки. Внутрішній діаметр камери $d_{\text {вн }}=0.26 \mathrm{M}$, висота камери $h_{\kappa}=0.15 \mathrm{M}$. Площа внутрішньої дзеркальної поверхні $S_{2}=0.34 \mathrm{M}^{2}$. Муфельна піч мала такі самі розміри.

Форма заготовки - циліндр. Висота заготовки $h_{u}=$ $0.016 \mathrm{M}$, радіус основи дорівнює $r=0.01 \mathrm{м}$. Площа поверхні циліндричної заготовки без урахування нижньої основи $S_{1}=0.001314 \mathrm{M}^{2}$. Маса заготовки $m=0.05 \kappa г$. 


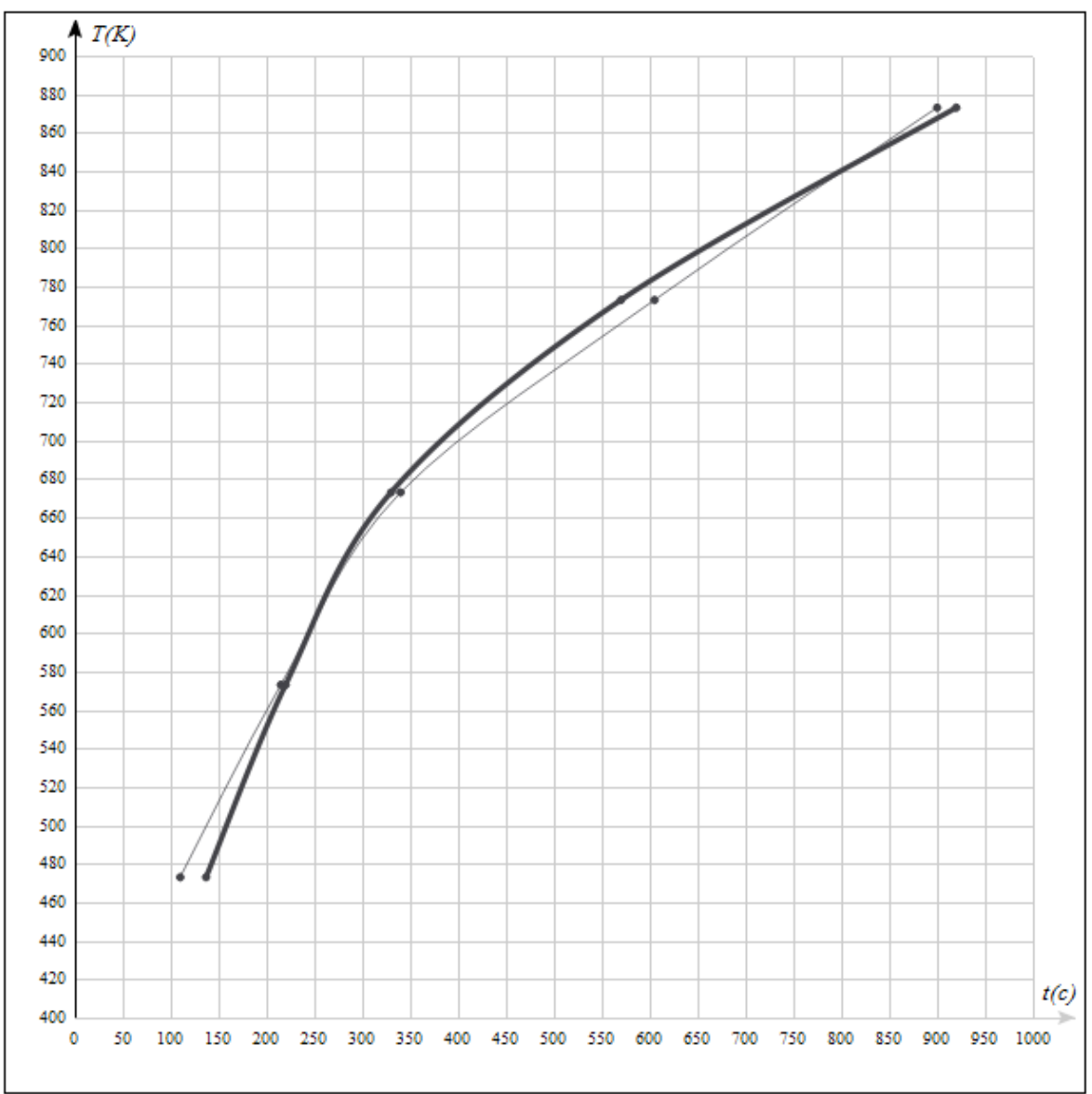

Рис. 1. Залежність температури заготовки з карбонільного заліза від часу нагріву в муфельній печі (жирна лінія - розрахункові дані, тонка лінія - експериментальні)

Інтенсивність випромінювання визначається конструкцією камери спікання, потужністю випромінювача, спектром випромінювання. При двох лампах загальної потужністю 6 кВт кожна ультрафіолетового випромінювання (довжина хвилі 400 нм) інтенсивність випромінювання в камері була рівною $I=10^{4} \frac{\mathrm{BT}}{\mathrm{M}^{2}}$. Коефіцієнт поглинання порошкового карбонільного залізаз радіусом частинок $r=3 \cdot 10^{-6}$ м дорівнює $\alpha=0.9$. Теплоємність карбонільного заліза дорівнює $c_{\rho}=460 \frac{\text { Дж }}{\mathrm{KT} \cdot \mathrm{K}}$. Початкова температура нагріву $T_{0}^{\rho}=293 \mathrm{~K} .3$ огляду на початкові умови розрахуємо час нагрівання заготовки до температур в інтервалі $(473 К-973 К)$ при нагріванні у муфельній печі й у вакуумній камері з ультрафіолетовими двома лампами. Для порівняльних розрахунків приймаємо інтенсивність випромінювання у муфельній камері рівній також $I=10^{4} \frac{\mathrm{BT}}{\mathrm{m}^{2}}$. У разі інфрачервоного випромінювання, яке присутнє в муфельній печі, енергія кванта мала (складає не більше $10^{-3} \mathrm{eB}$ ), тому вимушене випромінювання відсутнє (перетин переходу $\delta=0$ ).

У табл. 1 наведені розрахункові й експериментальні дані по нагріванню заготовки в муфельній печі. Рис. 1 графічно демонструє різницю між отриманими даними.
Таблиця 1. Розрахункові й експериментальні дані по нагріванню заготовки в муфельній печі

\begin{tabular}{|c|c|c|}
\hline $\begin{array}{c}\text { Температура } \\
\text { нагріву, K }\end{array}$ & $\begin{array}{c}\text { Розрахункові } \\
\text { дані, } \mathbf{c}\end{array}$ & $\begin{array}{c}\text { Експериментальні } \\
\text { дані, } \mathbf{c}\end{array}$ \\
\hline 473 & 137 & 110 \\
\hline 573 & 220 & 215 \\
\hline 673 & 330 & 340 \\
\hline 773 & 570 & 605 \\
\hline 873 & 920 & 900 \\
\hline
\end{tabular}

Як бачимо з табл. 1, результати розрахунку процесу нагрівання заготовки до ізотермічної температури 873 К за рівнянням теплового балансу (7) цілком відповідають експериментальним даним. За такої інтенсивності випромінювання в такій муфельній печі температура нагрівання 873 К максимальна. Цей експеримент потрібен був виключно для порівняння процесів нагріву і спікання в електромагнітних полях ультрафіолетового діапазону, для виявлення особливостей і оцінки ефективності нових способів спікання.

Зробимо розрахунок додаткового тепла, яке виділяється всередині заготовки, за рахунок вимушеного випромінювання внаслідок поглинання фотонів. 


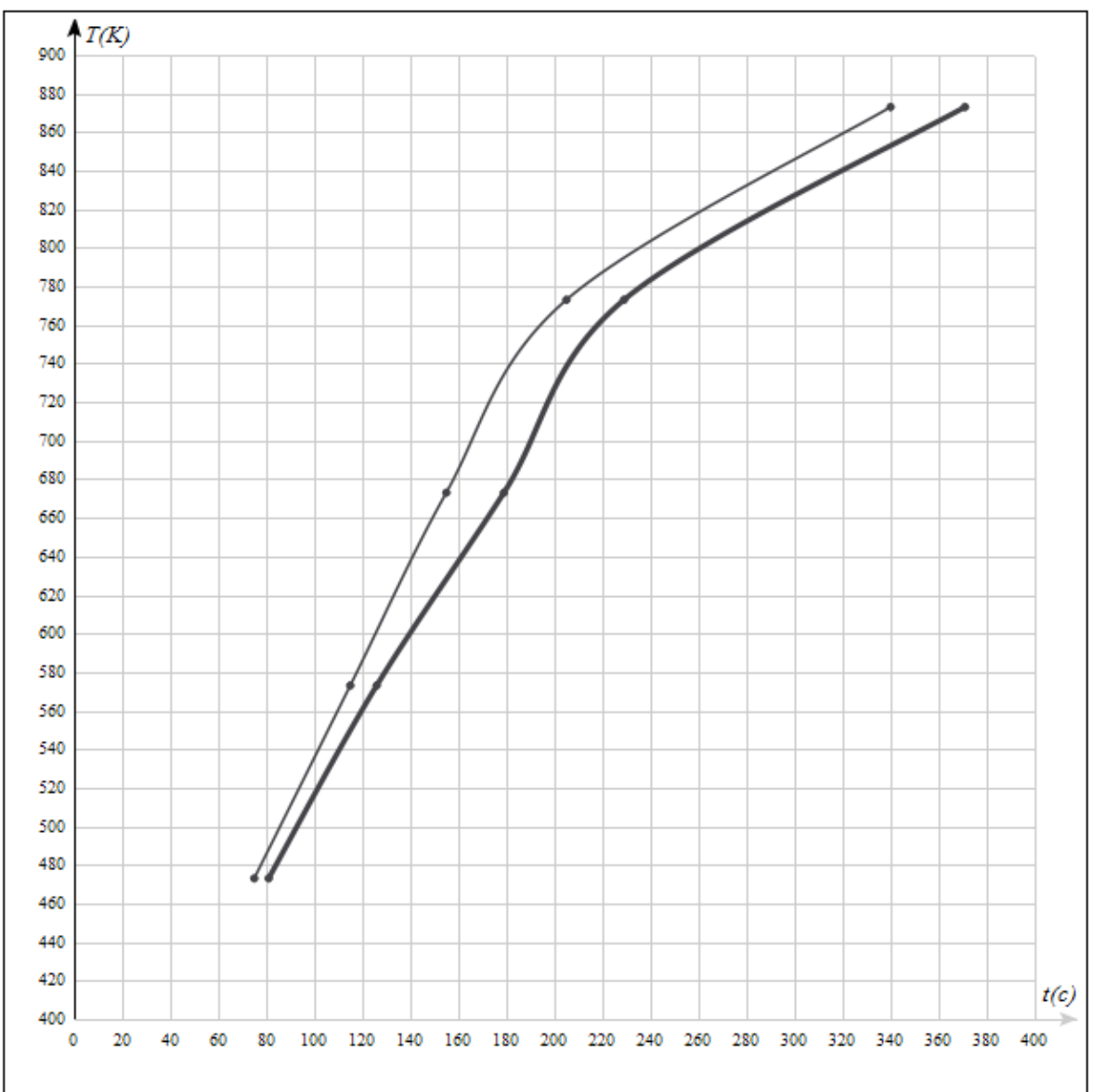

Рис. 2. Залежність температури заготовки з карбонільного заліза від часу нагріву у вакуумній камері ультрафіолетовим випромінюванням (товста лінія - розрахункові дані, тонка лінія - експериментальні)

Кількість атомів заліза в. заготівлі визначається за формулою: $\mathrm{N}=\frac{\mathrm{m}}{\mathrm{m}_{\text {ат }}}=\frac{0.05}{9.11 \cdot 10^{-31}}=0.6 \cdot 10^{29}$. Як було сказано вище, у вимушеному випромінюванні беруть участь приблизно половина атомів, рівна $0.3 \cdot 10^{29}$.

Число фотонів, що падають на поверхню заготовки, визначається виразом:

$$
\mathrm{n}=\frac{\mathrm{I}}{\mathrm{E}_{\mathrm{KB}}} \frac{\mathrm{S}_{1}}{\mathrm{~S}_{2}}=1.768 \cdot 10^{20}\left[\frac{1}{M^{2} \cdot c}\right] .
$$

Щільність ймовірності вимушеного випромінювання:

$$
W=n \cdot \delta=11.58 \cdot 10^{-10}\left[\frac{1}{c}\right] .
$$

Кількість додаткового тепла, яке утворюється всередині спікаємої заготовки:

$$
Q_{3}=N \cdot W \cdot E_{\kappa в}=23.24 Д \varkappa .
$$

3 урахуванням цієї добавки енергії за формулою (8) знаходимо час нагрівання заготовки до температури 473 К...873К. У табл. 2 та рис. 2 наведені результа- ти розрахунку й експериментальні дані по ультрафіолетовому нагріву.

Таблиця 2. Розрахункові та експериментальні дані по нагріванню ультрафіолетовим випромінюванням

\begin{tabular}{|c|c|c|}
\hline $\begin{array}{c}\text { Температура } \\
\text { нагріву, К }\end{array}$ & $\begin{array}{c}\text { Розрахункові } \\
\text { дані, с }\end{array}$ & $\begin{array}{c}\text { Експериментальні } \\
\text { дані, с }\end{array}$ \\
\hline 473 & 81 & 75 \\
\hline 573 & 126 & 115 \\
\hline 673 & 179 & 155 \\
\hline 773 & 229 & 205 \\
\hline 873 & 371 & 340 \\
\hline
\end{tabular}

На графіку (рис. 3) показані процеси зміни температури заготовки при іiі нагріві у муфельній печі та при електромагнітному нагріванні ультрафіолетовим випромінюванням. Час розігріву заготовки до температури 873К при електромагнітному нагріванні ультрафіолетовим випромінюванням скорочується у три рази порівняно з нагріванням інфрачервоним випромінюванням у муфельних печах, що сприятливо впливає на характеристиках спікаємих матеріалів. 


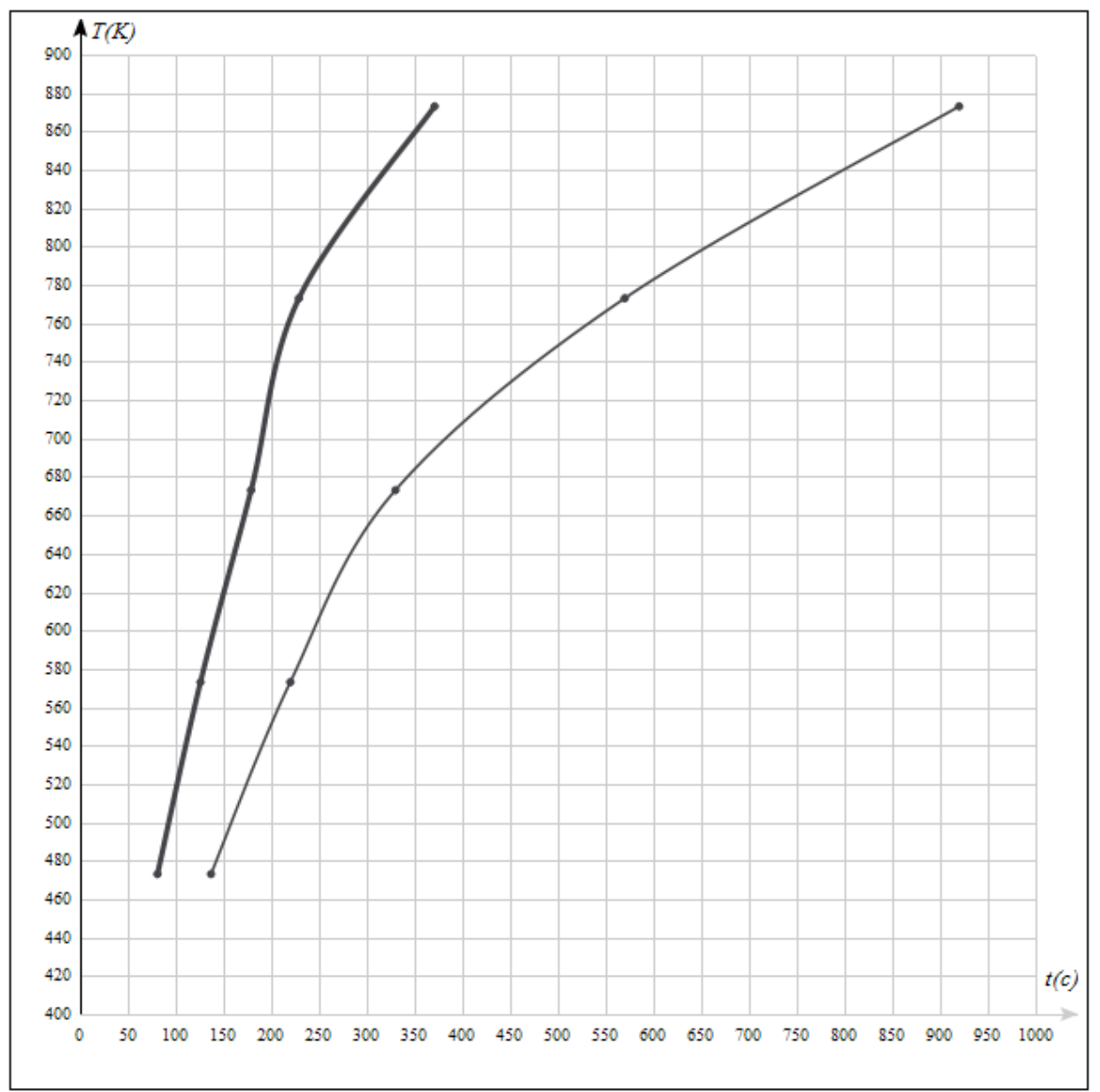

Рис. 3. Залежність температури заготовки з карбонільного заліза від часу нагріву в муфельній печі й у вакуумній камері ультрафіолетовим випромінюванням (тонка лінія муфельна піч, товста лінія - ультрафіолетовий нагрів)

\section{ОБГОВОРЕННЯ ОТРИМАНИХ РЕЗУЛЬТАТІВ}

Проведене дослідження дозволило знайти спосіб скорочення тривалості розігріву пресованих порошкових заготовок до температури спікання. Отримані результати дали можливість зрозуміти природу впливу ультрафіолетового випромінювання на дифузійні процеси при спіканні. Побудоване рівняння теплового балансу допоможе дослідникам, що працюють в області порошкової металургії, розраховувати необхідні параметри спікання.

\section{ВИСНОВКИ}

При нагріванні заготовки 3 металевого порошку електромагнітним полем ультрафіолетового діапазо- ну, в якому присутні кванти 3 великими значеннями, проявляються ефекти енергетичних переходів при взаємодії фотонів 3 атомами речовини. Додаткова енергія вимушеного випромінювання зростає при збільшенні інтенсивності випромінювання. Така надбавка енергії присутня не тільки на стадії розігріву, але і на стадії ізотермічного спікання. За рахунок ефекту поглинання атомами речовини падаючих на поверхню фотонів скорочується час розігріву і подальшого ізотермічного спікання в три-чотири рази. Це забезпечить загалом поліпшення економічних показників виробничих процесів виготовлення деталей з електропровідних матеріалів.

\section{REFERENCES}

[1] Science 4 Technology (2017). Iskro-plazmennoe spekanie poroshkovyih kompozitsiy [Spark-plasma sintering of powder compositions]. Retrived from: https://science4technology.com/post/iskro-plazmennoe-spekanie-poroshkovyh-kompozicij/.

[2] Metalspace (2013). Proizvodstvo materialov metodom poroshkovoy metallurgii. Goryachee pressovanie [Production of materials by powder metallurgy. Hot pressing]. Retrived from: https://metalspace.ru/education-career/osnovy-metallurgii/ poroshkovaya-metallurgiya/661-goryachee-pressovanie.html.

[3] Libenson G.A. (1975). Osnovyi poroshkovoy metallurgii [Powder metallurgy basics]. Moskva: Metallurgiya [in Russian].

[4] Libenson G.A. (1990). Proizvodstvo poroshkovyih izdeliy. Uchebnik. [Production of powder products. Textbook]. Moskva: Metallurgiya [in Russian]. 
[5] Kiparisov S.S. (1980). Poroshkovaya metallurgiya [Powder metallurgy]. Moskva: Metallurgiya [in Russian].

[6] Tsukerman S.A. (1958). Poroshkovaya metallurgiya [Powder metallurgy]. Moskva: Publishing House of the USSR Academy of Sciences [in Russian].

[7] Ayzenkol B.F. (1969). Uspehi poroshkovoy metallurgii [Advances in Powder Metallurgy]. Moskva: Metallurgiya [in Russian].

[8] Libenson M.N., Yakovlev E.B., Shandyibina G.D., (2008). Vzaimodeystvie lazernogo izlucheniya s veschestvom. Chast 1 [The interaction of laser radiation with matter. Part 1]. Sankt-Peterburg: GU ITMO [in Russian].

[9] Libenson M.N., Yakovlev E.B., Shandyibina G.D., (2014). Vzaimodeystvie lazernogo izlucheniya s veschestvom. Chast 2 [The interaction of laser radiation with matter. Part 2]. Sankt-Peterburg: GU ITMO [in Russian].

[10] Mazanko V.F. (2012). Diffuziya v usloviyah odnovremennogo deystviya postoyannogo magnitnogo polya, kvazistaticheskoy i impulsnoy deformatsiy i ultrazvukovyih kolebaniy pri komnatnoy i povyishennyih temperaturah [Diffusion under conditions of simultaneous action of a constant magnetic field, quasistatic and pulsed deformations and ultrasonic vibrations at room and elevated temperatures]. Samara: Izvestiya samarskogo nauchnogo tsentra rossiyskoy akademii nauk, t. 14, № 4.

[11] Pokoev A.V. (1999). Vliyanie postoyannogo magnitnogo polya na zernogranichnuyu diffuziyu 63Ni v polikristallicheskom kobalte [The effect of a constant magnetic field on the grain-boundary diffusion of 63Ni in polycrystalline cobalt]. Minsk: 3-ya mezhdunarodnaya konferentsiya Vzaimodeystvie izlucheniya s tverdyim telom.

[12] Pokoev A.V. (1997). Anizotropiya diffuzii 63Ni v monokristallicheskom kremnistom zheleze v postoyannom magnitnom pole[Anisotropy of 63Ni diffusion in single-crystal silicon iron in a constant magnetic field]. Samara: Pisma v ZhTF, tom 23, № 5.

[13] Milyutin V.A. (2017). Vliyanie silnogo magnitnogo polya na evolyutsiyu strukturyi i kristallograficheskoy teksturyi v protsesse otzhiga deformirovannyih i amorfnyih ferromagnitnyih metallicheskih splavov [The influence of a strong magnetic field on the evolution of the structure and crystallographic texture during the annealing of deformed and amorphous ferromagnetic metal alloys]. Ekaterinburg: Federalnoe gosudarstvennoe byudzhetnoe uchrezhdenie nauki institut fiziki metallov imeni M.N. Miheeva uralskogo otdeleniya rossiyskoy akademii nauk.

[14] Milyutin V.A. (2018). Vliyanie silnogo magnitnogo polya na fazovyie i strukturnyie prevrascheniya $\mathrm{v}$ ferromagnitnyih splavah [The influence of a strong magnetic field on phase and structural transformations in ferromagnetic alloys]. Letters on Materials 8 (1), pp. 59-65.

[15] Kitaygorodskiy A.I. (1973). Vvedenie v fiziku [Introduction to physics]. Moskva: Nauka [in Russian].

[16] Landau L.D., Lifshits, E.M. (2004). Kvantovaya mehanika.Nerelyativistskaya teoriya [Quantum mechanics.Nonrelativistic theory]. Moskva: Fizmatlit [in Russian].

[17] Libenson G.A., Lopatin V.Yu., Komarnitskiy V. (2002). Protsessyi poroshkovoy metallurgii [Powder metallurgy processes]. Moskva: Misis [in Russian].

[18] Samsonov V. (1976). Svoystva elementov. Chast 1. Fizicheskie svoystva [Properties of the elements. Part 1.Physical properties]. Moskva: Metallurgiya [in Russian].

[19] Berestetskiy V.B., Lifshits E.M., Pitaevskiy L.P. (1989). Kvantovaya elektrodinamika. [Quantum electrodynamics.Third Edition]. Moskva: Nauka [in Russian].

[20]Prohorov A.M. (1998). Fizicheskaya entsiklopediya.Urovni energii [Physical Encyclopedia.Energy levels]. Moskva: Sovetskaya entsiklopediya [in Russian].

[21] Mikaelyan A.L., Ter-Mikaelyan M.L., Turkov Y.G. (1967). Opticheskie generatoryi na tverdom tele [Solid State Optical Generators]. Moskva: Sovetskoe radio [in Russian].

[22] Lifshits E.M. (1976). Bolshaya sovetskaya entsiklopediya. Teploemkost. Red. A.M. Prohorov. [Great Soviet Encyclopedia. Heat capacity. Ed. A.M. Prokhorov]. Moskva: Velikaya Sovetskaya Entsiklopediya [in Russian].

[23] Ahiezer A.I., Berestetskiy V.B. (1969). Kvantovaya elektrodinamika [Quantum electrodynamics]. Moskva: Nauka [in Russian].

[24] Belenkiy S.M. (1992). Fizicheskaya entsiklopediya. Rasseyanie mikrochastits. Red. A.M. Prohorov [Physical Encyclopedia. Microparticle scattering. Ed. A.M. Prokhorov]. Moskva: Sovetskaya entsiklopediya [in Russian].

[25] Shirokov Y.M., Yudin N.P (1972). Yadernaya fizika [Nuclear Physics]. Moskva: Nauka [in Russian].

[26] Nuclear physics on the Internet (2011). Vzaimodeystvie fotonov s veschestvom [The interaction of photons with matter]. Retrived from: http://nuclphys.sinp.msu.ru/ihem/ihem03.htm.

\section{СПИСОК ВИКОРИСТАНОЇ ЛІТЕРАТУРИ}

[1] Science 4 Technology (2017). Искро-плазменное спекание порошковых композиций. URL: https://science4technology. com/post/iskro-plazmennoe-spekanie-poroshkovyh-kompozicij/.

[2] Metalspace (2013). Производство материалов методом порошковой металлургии. Горячее прессование. URL: https:// metalspace.ru/education-career/osnovy-metallurgii/poroshkovaya-metallurgiya/661-goryachee-pressovanie.html.

[3] Либенсон Г.А. (1975). Основы порошковой металлургии. Москва : Металлургия.

[4] Либенсон Г.А. (1990). Производство порошковых изделий : учебник. Москва : Металлургия;

[5] Кипарисов С.С. (1980). Порошковая металлургия. Москва : Металлургия.

[6] Цукерман С.А. (1958). Порошковая металлургия. Москва : Издательство Академии Наук СССР. 


\section{ЕЛЕКТРОЕНЕРГЕТИКА, ЕЛЕКТРОТЕХНІКА ТА ЕЛЕКТРОМЕХАНІКА № 3 - 2019}

[7] Айзенколь Б.Ф. (1969) Успехи порошковой металлургии. Москва : Металлургия.

[8] Либенсон М.Н., Яковлев Е.Б., Шандыбина Г.Д. (2008). Взаимодействие лазерного излучения с веществом. Ч. 1. Санкт-Петербург : ГУ ИТМО.

[9] Либенсон М.Н., Яковлев Е.Б., Шандыбина Г.Д. (2014). Взаимодействие лазерного излучения с веществом. Ч. 2. Санкт-Петербург : ГУ ИТМО.

[10] Мазанко В.Ф. (2012). Диффузия в условиях одновременного действия постоянного магнитного поля, квазистатической и импульсной деформаций и ультразвуковых колебаний при комнатной и повышенных температурах. Самара : Известия самарского научного центра российской академии наук, т. 14, № 4.

[11] Покоев А.В. (1999). Влияние постоянного магнитного поля на зернограничную диффузию 63Ni в поликристаллическом кобальте. Минск : 3-я международная конференция «Взаимодействие излучения с твердым телом».

[12] Покоев А.В. (1997). Анизотропия диффузии 63Ni в монокристаллическом кремнистом железе в постоянном магнитном поле. Самара : Письма в ЖТФ, т. 23, № 5.

[13] Милютин В.А. (2017). Влияние сильного магнитного поля на эволюцию структуры и кристаллографической текстуры в процессе отжига деформированных и аморфных ферромагнитных металлических сплавов. Екатеринбург : Федеральное государственное бюджетное учреждение науки институт физики металлов имени М.Н. Михеева уральского отделения российской академии наук.

[14] Милютин В.А. (2018). Влияние сильного магнитного поля на фазовые и структурные превращения в ферромагнитных сплавах. Letters on Materials 8 (1), pp. 59-65.

[15] Китайгородский А.И. (1973). Введение в физику. Москва : Наука.

[16] Ландау Л.Д., Лифшиц Е.М. (2004). Квантовая механика. Нерелятивистская теория. Москва : Физматлит.

[17] Либенсон Г.А., Лопатин В.Ю., Комарницкий В. (2002). Процессы порошковой металлургии. Москва : Мисис.

[18] Самсонов В. (1976). Свойства элементов. Ч. 1. Физические свойства. Москва : Металлургия;

[19] Берестецкий В.Б., Лифшиц Е.М., Питаевский Л.П. (1989). Квантовая электродинамика. Москва : Наука.

[20] Уровни энергии. Физическая энщиклопедия. (1998). Москва.

[21] Микаэлян А.Л., Тер-Микаэлян М.Л., Турков Ю.Г. (1967). Оптические генераторы на твердом теле. Москва : Советское радио.

[22] Лифшиц Е.М. (1976) Теплоемкость. Большая советская энциклопедия / ред. А.М. Прохоров. Москва : Великая Советская Энциклопедия.

[23] Ахиезер А.И., Берестецкий В.Б. (1969). Квантовая электродинамика. Москва : Наука.

[24] Беленький С.М. (1992). Рассеяние микрочастиц. Физическая энщиклопедия / ред. А.М. Прохоров. Москва : Советская энциклопедия;

[25] Широков Ю.М., Юдин Н.П. (1972). Ядерная физика. Москва : Наука.

[26] Ядерная физика в Интернете. Взаимодействие фотонов с веществом. URL: http://nuclphys.sinp.msu.ru/ihem/ihem03. htm. 